\title{
Oídos caprinos
}

\section{Goat ears}

\section{Albert Polania Mosquera ${ }^{1}$}

${ }^{1}$ Fundación Cardio Infantil, Instituto de Cardiología, Bogotá, Colombia

Rev Argent Radiol 2022;85(Suppl S1):S18-S19.

Paciente femenina de 17 años que consulta al servicio de urgencias por cuadro de cefalea intensa. Después del examen físico riguroso, se ordena la realización de una tomografía computada (TC) cerebral sin contraste, la cual no muestra hallazgos patológicos de importancia, ordenándose manejo sintomático.

En las imágenes se presenta un corte en reconstrucción coronal a nivel de la fosa cerebral media ( - Fig. 1), donde se localiza la porción ósea de ambos huesos temporales, identificando la imagen de dos cabras macho mirándose cara a cara, un instante antes de chocar sus cuernos (—Fig. 2). La imagen del cuello de los caprinos está

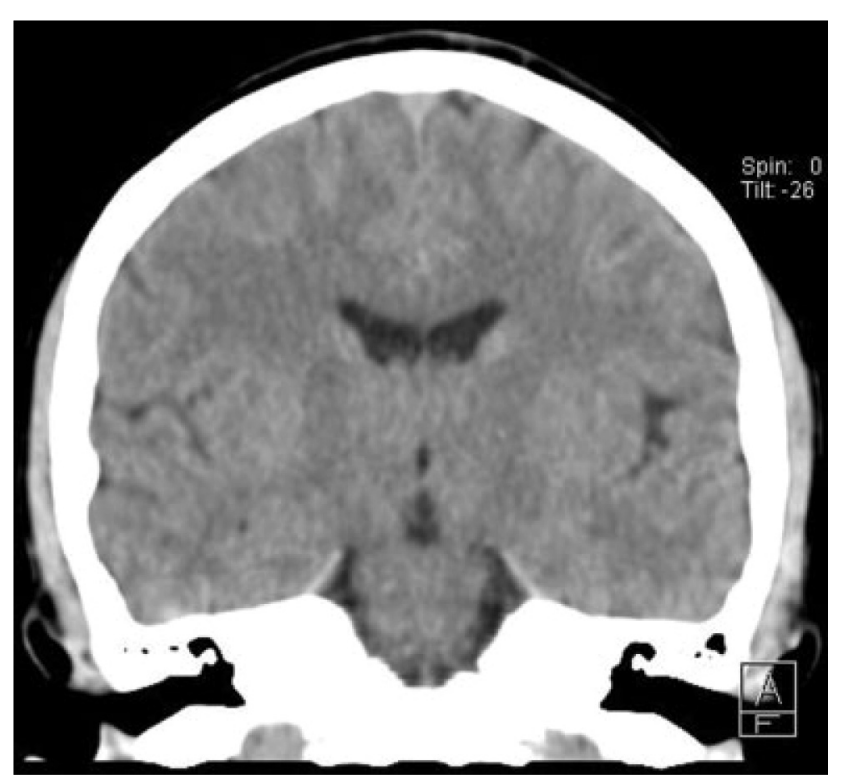

Fig. 1 Reconstrucción coronal de TC cerebral sin contraste.

received

June 1,2020

accepted

July 23, 2020

published online

August 27, 2020
Address for correspondence Albert Polania Mosquera, MD, Fundación Cardioinfantil - Instituto de Cardiología, Bogotá, Código Postal: 110131, Colombia (e-mail: alber.polania@urosario.edu.co).

conformada por los conductos auditivos externos y la de sus cabezas por las diferentes partes del oído medio, siendo la imagen de los cuernos la prolongación superior de esta cavidad (epitímpano).

La cabra doméstica (Capra aegagrus hircus) es una especie animal que se puede encontrar en todo el mundo en casi todos los tipos de clima (-Fig. 3). Existen alrededor de 200

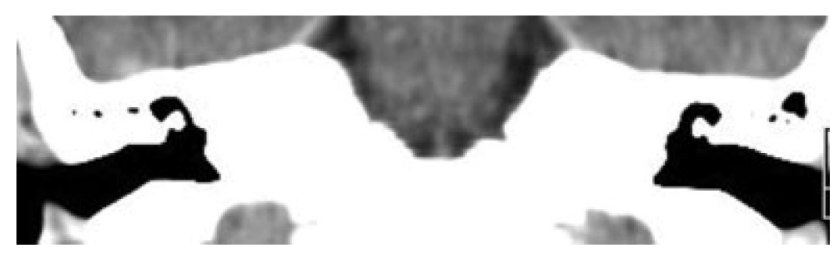

Fig. 2 Imagen magnificada de ambos huesos temporales.

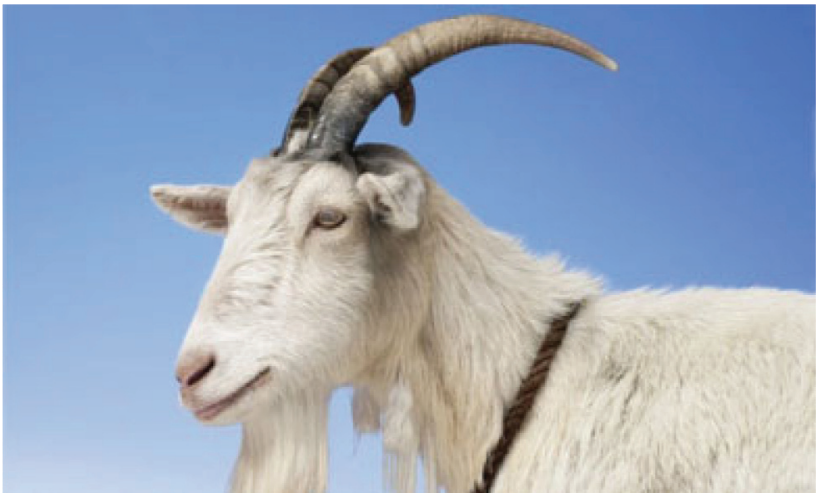

Fig. 3 Imagen de una cabra doméstica.

(c) 2020. Asociación Civil Sociedad Argentina de Radiología and Federacion Argentina de Asociaciones de Radiología, Diagnóstico por Imágenes y Terapia Radiante. All rights reserved.

This is an open access article published by Thieme under the terms of the Creative Commons Attribution-NonDerivative-NonCommercial-License, permitting copying and reproduction so long as the original work is given appropriate credit. Contents may not be used for commercial purposes, or adapted, remixed, transformed or built upon. (https://creativecommons.org/ licenses/by-nc-nd/4.0/)

Thieme Revinter Publicações Ltda., Rua do Matoso 170, Rio de Janeiro, RJ, CEP 20270-135, Brazil 
razas conocidas y el tamaño, así como el color de su pelaje, puede variar ampliamente. Los machos reciben distintos tipos de nombres como cabro, chivato o macho cabrío y son los únicos que desarrollan cornamenta. Es común, en algunas razas, ver a los machos peleando por celo, chocando sus cuernos con gran violencia en repetidas ocasiones. 